\title{
脳動脈瘤クリッピング術後の再発例・新生例の検討
}

$\begin{array}{llllllll}\text { 久保田 } & \text { 基 } & \text { 夫 } & \text { 星 } & \text { 誠一郎* } & \text { 砂 } & \text { 田 } & \text { 荘 } \\ \text { 角 南 } & \text { 兼 } & \text { 朗* } & \text { 佐 伯 直 勝 } & \text { 山 } & \text { 浦 } & \text { 晶 }\end{array}$

\section{A Retrospective Study on Recurrent or New Intracranial Aneurysms after Neck Clipping \\ by}

\section{Motoo Kubota, M.D., Seiichiro Hoshi, M.D.*, Souichi Sunada, M.D.*, Kenro Sunami, M.D.*, Naokatsu Saeki, M.D., and Akira Yamaura, M.D.}

from

Department of Neurosurgery, School of Medicine, Chiba University, and *Department of Neurosurgery, Kawatetsu Chiba Hospital

It has been recognized that surgically-treated, even successfully clipped, intracranial aneurysms may regrow in time. In this study, the authors have tried to determine how many surgically treated aneurysms are likely to recur. Between 1969 and 1992 they have clipped 417 saccular aneurysms in 359 patients. After excluding 26 patients who soon died postoperatively, of the remaining 333 patients, 257 patients (77\%) were followed up and retrospective review of these patients has revealed that 83 patients underwent IV-DSA to determine whether they had an aneurysmal recurrence. The follow-up period for those patients was $8.8 \pm 5.3$ years ( $1 \sim 25$ years).

Five of these follow up patients $(1.9 \%)$ were known to have experienced rebleeding, based on their medical records or from a telephone interview. In one of these five patients, an aneurysmal recurrence was confirmed by cerebral angiography. With regard to the ramaining 4 patients, cerebral angiography revealed 6 newly developed aneurysms.

As a result of the postoperative IV-DSA study of 83 patients, 2 cases were diagnosed as having had an aneurysmal recurrence. An aneurysmal recurrence was seen proximal to the clip in one patient, and contralateral to the previous aneurysm in another patient.

The reported incidence of an initial subarachnoid hemorrhage in the general population varies from 11 to $16 /$ 100,000 (population)/year. Based on our findings of a second subarachnoid hemorrhage in our surgically treated patients, we have roughly calculated the incidence of a recurrent subarachnoid hemorrhage to be about 221/ 100,000 /year. Therefore, patients who have undergone aneurysmal surgery have a high risk of developing a new aneurysm and /or an aneurysmal recurrence. Considering the great length of time it takes for an aneurysm to recur, a long-term follow up of over ten years should be established. Further, IV-DSA evaluations have proven useful for evaluating an aneurysmal recurrence.

(Received August 5, 1993 ; accepted September, 1995)

Key words : aneurysm, clipping, recurrence, de novo, IV-DSA

Jpn J Neurosurg (Tokyo) $5: 29-36,1996$

千葉大学医学部脳神経外科 $/ \overline{\mathrm{T}} 260$ 千葉市中央区亥鼻 1-8-1〔連絡先：久保田基夫〕

Address reprint requests to : Motoo Kubota, M.D., Department of Neurosurgery, Chiba University School of Medicine, 1-8-1 Inohana, Chuo-ku, Chiba-shi, Chiba 260, Japan

*川鉄千葉病院脳神経外科 
Table 1 Summary of 7 cases

\begin{tabular}{|c|c|c|c|c|c|c|c|c|}
\hline \multirow{2}{*}{$\begin{array}{l}\text { Case } \\
\text { No. }\end{array}$} & \multicolumn{3}{|c|}{ First admission } & \multicolumn{3}{|c|}{ Second admission } & \multirow{2}{*}{$\begin{array}{l}\text { Recurrence } \\
\text { or de novo }\end{array}$} & \multirow{2}{*}{ Outcome } \\
\hline & Age & Sex & Aneurysm & Age & Interval & Aneurysm & & \\
\hline \multicolumn{9}{|l|}{$\mathrm{SAH}$} \\
\hline 1 & 30 & $\mathrm{~F}$ & L. PCoA & 52 & $22 y$ & L. PCoA & recurrence & dead \\
\hline 2 . & 52 & $\mathrm{~F}$ & R. PCoA & 66 & $14 y$ & L. $\mathrm{PCoA}$ & de novo & poor \\
\hline 3 . & 51 & $\mathrm{~F}$ & $\mathrm{ACoA}$ & 63 & $12 y$ & R. PCoA & de novo & good \\
\hline 4 . & 39 & M & L. MCA & 47 & $8 y$ & R. MCA & de novo & dead \\
\hline 5 . & 18 & $\mathrm{~F}$ & L. ICB & 26 & $8 \mathrm{y}$ & $\begin{array}{l}\text { R. MCA } \\
\text { L. PCoA* } \\
\text { L. AChA* }\end{array}$ & de novo & good \\
\hline \multicolumn{9}{|l|}{ IV-DSA } \\
\hline 6 & 46 & M & $\mathrm{ACoA}$ & 53 & $7 y$ & $\mathrm{ACoA}$ & recurrence & good \\
\hline 7. & 44 & $\mathrm{~F}$ & R. MCA & 49 & $5 y$ & R. MCA & recurrence & good \\
\hline
\end{tabular}

${ }^{*}$ : newly developed but unruptured aneurysms

SAH : subarachnoid hemorrhage IV-DSA : intravenous digital subtraction angiography

PCoA : posterior communicating artery ACoA: anterior communicating artery AChA : anterior choroidal

artery ICB : internal carotid bifurcation MCA : middle cerebral artery $\quad$ L. : left $\quad$ R. : right

\section{はじめに}

脳動脈瘤頸部クリッピング術は, 破裂脳動脈瘤に対す る最も信頼しうる手術法である。しかし近年，術後数年 を経て動脈瘤が再発し，再出血をきたした症例が報告さ れている6) (10114)20121125)。また初回手術時の脳血管撮影で は認められなかった動脈瘤が, 新たに形成されていたと する報告もある819)11)13117191. ligation や wrapping 術後 の再出血率に関しては古くから検討されている が(8)2325)，クリッピング術に関して多数例を長期間追跡 調査した報告は少ない14)201)。

今回はクリッピング術後の動脈瘤の再発や新生の有無 を確認するために，川鉄千葉病院脳神経外科にてクリッ ピング術を行った全症例を対象として，アンケートおよ び電話インタビューによる追跡調查を行った。また希望 者に対して intravenous digital subtraction angiography（IV-DSA）を行い，動脈瘤再発の有無を検討した。

\section{対象および方法}

川鉄千葉病院では, 1968 年の脳神経外科開設以来 1992 年 3 月までに 359 例 (417 個) の脳動脈瘤クリッピング術 を行っている.このうち術後退院前に死亡した 26 例を除 く333 例を対象に追跡調查を行った。調查項目は, (1) 患 者の生死（死亡している場合にはその死因と死亡時期), (2) 退院後くも膜下出血の有無 (くも膜下出血がある場合 にはCT スキャンや脳血管撮影などにより診断が確定 しているかどうか) などである.

調査方法は現在外来通院中の患者は外来診療録を参考 にし，それ以外の患者にはアンケートを郵送した。アン
ケートのみで不明な点は, 直接電話インタビューを行い 確認した。また希望者に対してIV-DSA を行い, 脳動脈 溜の再発の有無を確認した。IV-DSA の方法は, 以前深 谷ら ${ }^{7)}$ が報告した方法に準じている. 術後 $2 \sim 16$ 年目の 患者 83 例に対し, 計 117 回行った。

\section{結 果}

現在外来通院中の患者も含め 333 例中 257 例 $(77 \%$ ） より回答が得られた。追跡期間は $1 \sim 25$ 年(平均 8.8 年) であった。 234 例は現在生存中であり，23 例は死亡して いた. 76 例からは回答が得られなかったが，このうち 45 例は転居により住所が不明でアンケートを郵送できな かった症例で, 残り 31 例はアンケートを郵送したが, 十 分な回答が得られなかった症例である。

転機の明らかな 257 例中, 脳動脈溜の再発または新生 と診断された患者は 7 例であった (Table 1)。このうち 5 例（症例 $1 \sim 5$ ）は, くも膜下出血の再出血により動脈 瘤の再発または新生が疑われた症例で，残り 2 例（症例 6，7）はIV-DSA により動脈瘤の再発が疑われた症例 である。このほかに 2 例が脳卒中と思われる発作により 死亡していた，死因としてくも膜下出血の可能性は否定 できないが，CT スキャンなどによる確定診断は行われ ていないため, 再出血例には加えていない.いずれも脳 神経外科開設初期の症例で，クリッピング術後 5 年目に 死亡している。死因を確認するため電話インタビューを 行ったが，すでにその配偶者も死亡しており，明確な回 答は得られなかった。

再出血例は 5 例とも再出血時には当科に搬送されてお り, CT スキャンにてくも膜下出血が確認され, 脳血管 


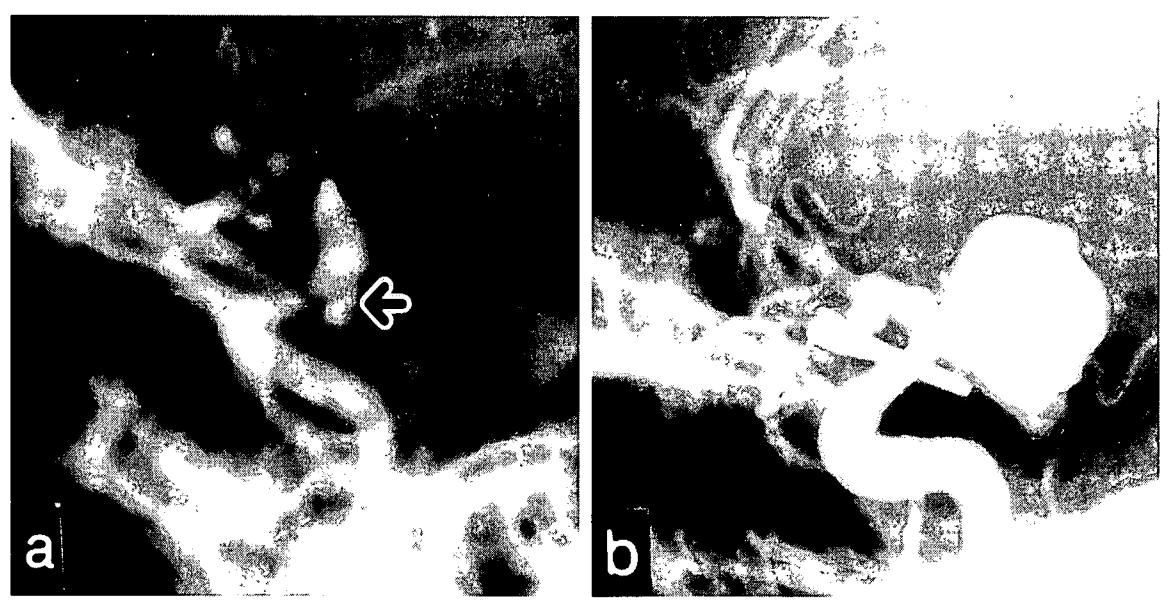

Fig. 1 Case 1

a : A left CAG on first admission (1968)

b : A left CAG on second admission (1990) shows a huge, aneurysmal dilatation just distal to the clip.
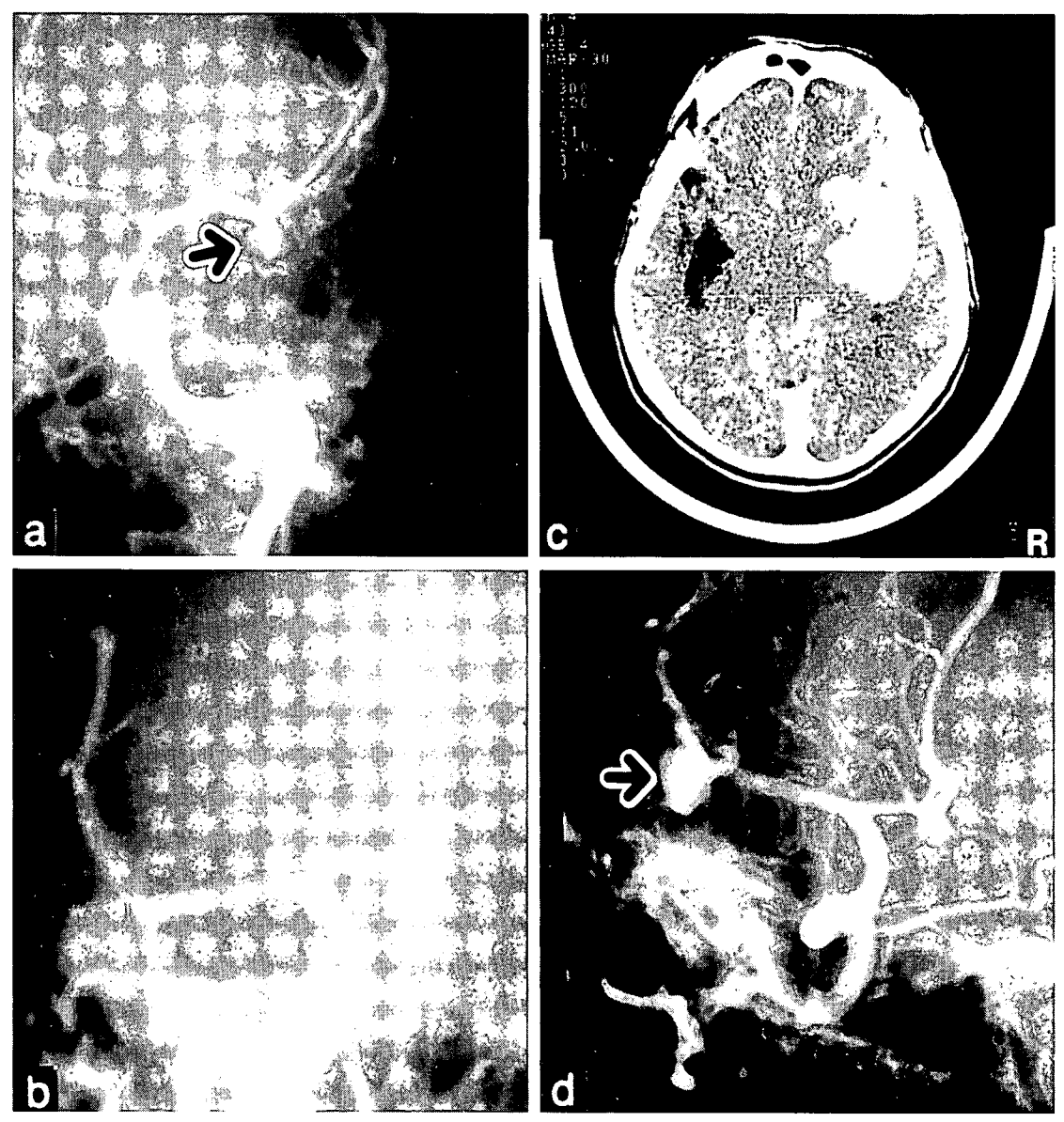

Fig. 2 Case 4

a, b : A left CAG (a) and a right CAG (b) on first admisson (1982)

c, d : A CT scan (c) and a right CAG (d) on the second admission (1990). A new aneurysmal formation is seen at the right MCA.

撮影も行われている. 初回出血時の年齢は平均 38.0 歳 (18〜 52 歳), 再出血までに要した期間は平均 12.8 年 ( 8 $\sim 14$ 年), 再出血時の年齢は平均 50.8 歳 (26 66 歳)で あった。また 4 例までが女性で，男性は 1 例のみであっ
た.再出血例のうちクリップの近傍に動脈瘤が形成され， 再発と判断されたのは 1 例のみであった（症例 1 , Fig. 1). 他の 4 例 (症例 $2 \sim 5$ ) は, 初回入院時とはまったく 別の場所に動脈瘤が形成されており，新生例と判断され 

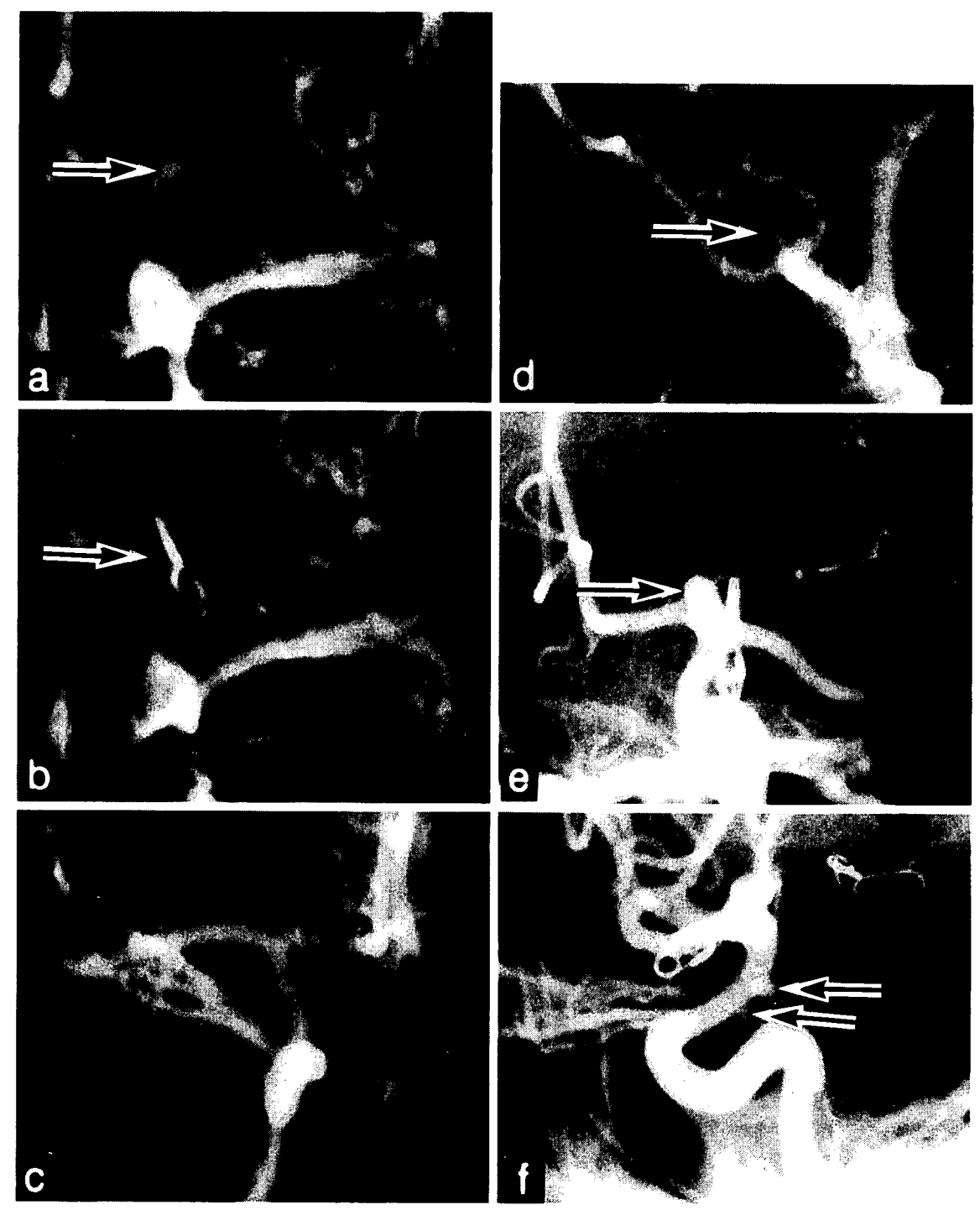

Fig. 3 Case 5

a : A preoperative left $\mathrm{CAG}$

b : A postoperative left CAG shows a part of the neck that remains unclipped (arrow, 1980).

c : No aneurysms are revealed in this right CAG (1980).

d : A follow-up right CAG on second admission (1988), 8 years after the first operation, revealed a new aneurysmal formation at the right MCA (arrow).

e, f : A left CAG shows that the initial clip has slipped out (arrow, e) and two aneurysmal formations at the left PCoA and AChA (arrows, f).

た. 4 例の新生例のうち 2 例（症例 $2,4 ）$ は, いわゆ る mirror image の位置に動脈瘤が形成されていた (Fig. 2). 症例 5 は今回検討した中で最も若年の症例であ るが， 8 年後にくも膜下出血にて再来院した時には，新 たな動脈瘤が 3 つ形成されており，初回手術時のクリッ プは slip out していた (Fig.3). CT スキャンおよび手 術所見より，新たに形成された右中大脳動脈瘤よりの出 血と考えられた．したがって今回の検討では，再出血率 は $1.9 \%(5 / 257$ 例) で，このうち動脈瘤の再発によるも のが 1 例 $(0.4 \%)$, 動脈瘤の新生によるものが 4 例 (1.5\%) であった.

IV-DSA は希望者 83 例に対し, 計 117 回行われた。こ
のうち動脈瘤の再発を認めた症例は 2 例（症例 6, 7 ） で，2 例とも脳血管撮影により動脈瘤が確認され，再ク リッピング術が行われた。症例 6 は前交通動脈瘤の症例 であるが，初回入院時は下向きの動脈瘤であり，再発時 にはクリップとは反対側（上向き）に動脈瘤が形成され ていた。最初の脳血管撮影にてクリップの反対側に小膨 瘤を認めており，これが 8 年の歳月を経て動脈瘤に成長 したものと判断された (Fig.4).また症例 7 もリップ の近傍であるが，明らかにクリップとは離れた場所に， 新たな動脈瘤が形成されていた（Fig.5). 

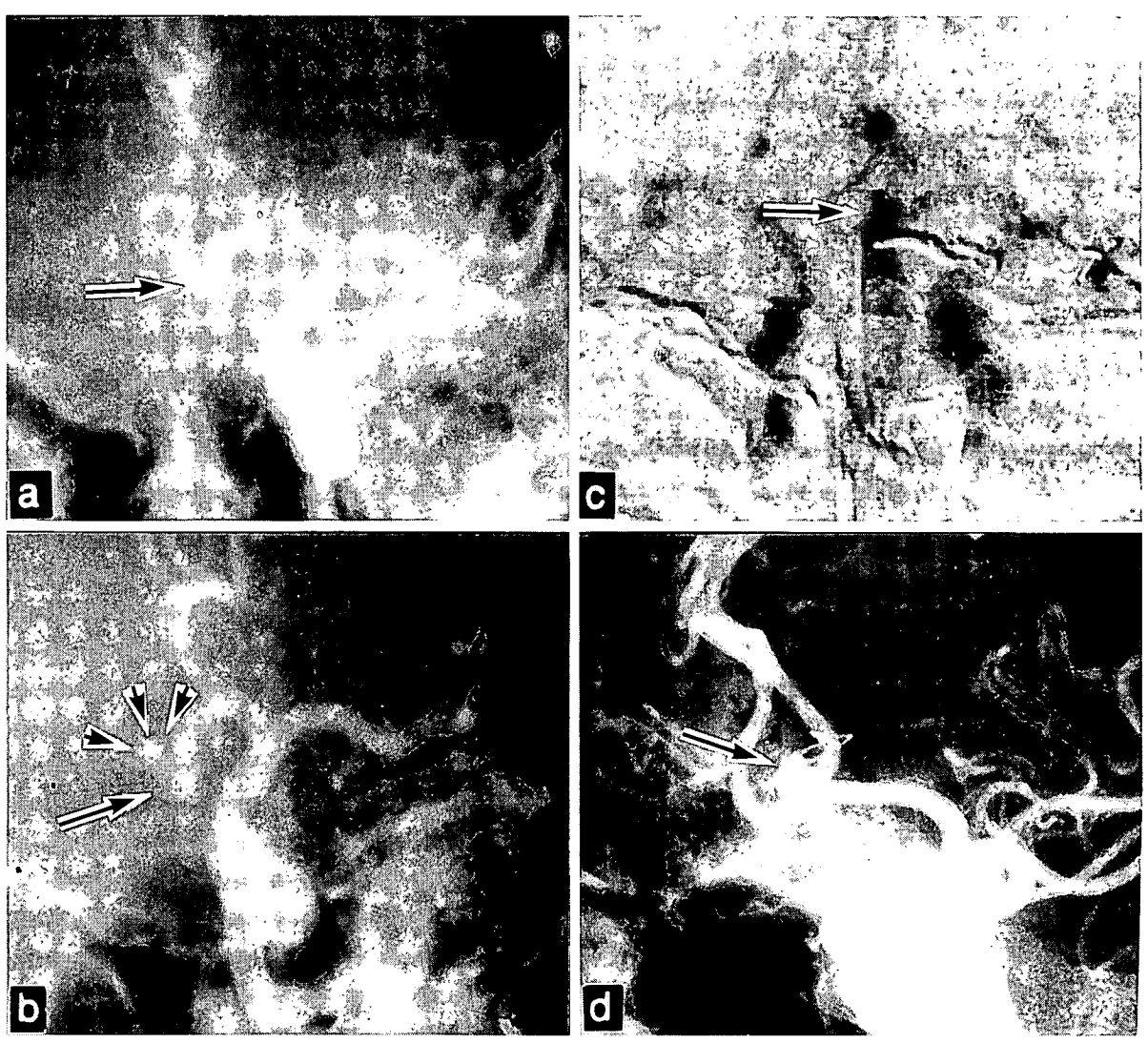

Fig. 4 Case 6

a, b : A left CAG (1982) shows a ACoA aneurysm (arrow) and a small bulge (arrow head).

c, d : Follow-up IV-DSA (c) and left CAG (d) (1989) revealed new aneurysmal formation at the same point where the small bulge had been previously seen.

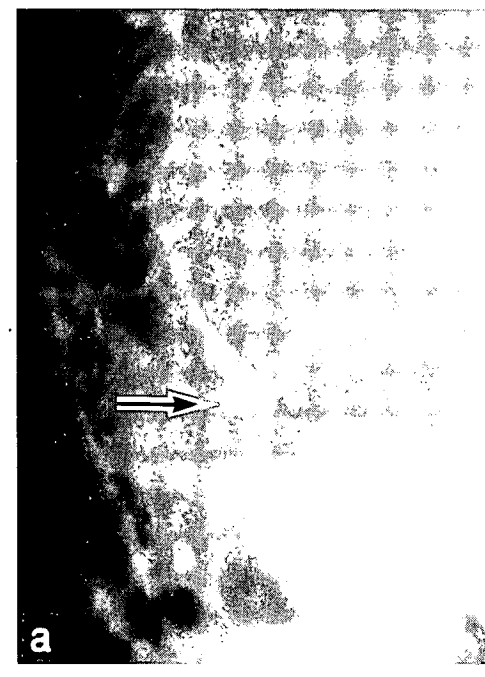

b

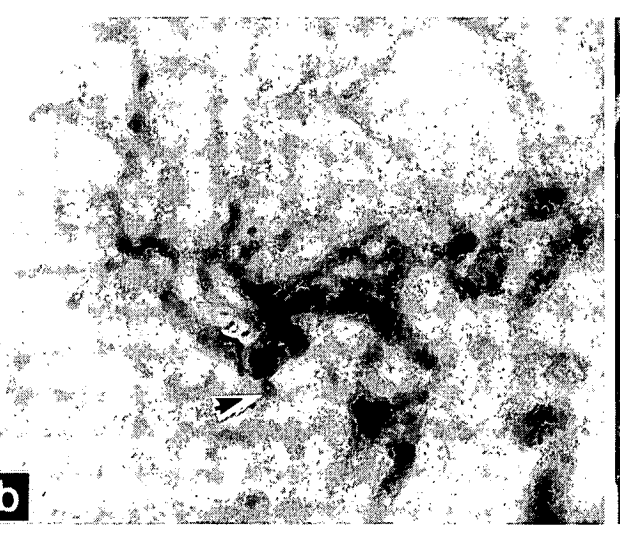

Fig. 5 Case 7

A right CAG (a), an IV-DSA (b) and a right CAG (c) that were taken 5 years after the initial operation (1985) show a small aneurysm proximal to the clip. Note the short distance between the clip and the newly developed aneurysm.

\section{考 察}

動脈瘤頸部クリッピング術は，破裂脳動脈瘤に対する 根治手術と考えられている。しかし術後数年を経て再発 した動脈瘤6)10)14)20121)25)や，最初の血管撮影では認めな
かったが, 数年後の血管撮影で新たな形成を認めた動脈 瘤の例が知られている819)11)13)17)19)。今回はクリッピン グ術後, 再発あるいは新生動脈瘤の発生率やその原因を 検討する目的で，川鉄千葉病院でクリッピング術を行っ た全症例を対象に,アンケートによる追跡調査を行った。 
また希望者に対し IV-DSA を行い, 動脈溜の術後再発お よび新生を検討した。アンケートは 333 例に対し行われ， 257 例（80\%）より回答を得た。また IV-DSA は，術後 $2 \sim 16$ 年目の患者 83 例に対して行われた。

\section{1] クリッピング術施行後の再出血}

くも膜下出血の再出血をきたした症例は 257 例中 5 例 で, 再出血率は $1.9 \%$ であった。再出血例の初回入院時の 平均年齢は 38.0 歳，再出血までの期間は 8〜 22 年(平均 12.8 年) であった。当院でクリッピング術が行われた全 症例の平均年齢は 52.0 歳であり, 再出血例には明らかに 若年発症例が多い傾向にあった，再出血時の平均年歯恰 50.8 歳であり，再出血を認めなかった症例の平均年齢と ほほ等しかった。また 5 例中 4 例までが女性であり，女 性例が多いのも再出血例の特徵といえるかもしれない. Lin ら ${ }^{14)} は ，$ 再出血または mass effectにより動脈瘤の 再発が確認された 19 症例について検討しているが，19 例中 14 例が女性で，初発時の年齢は 18〜 66 歳（平均 36.2 歳) で，14 例が 40 歳以下の症例であったと述べて いる。

術後の再出血に関し検討する時，出血の原因として動 脈瘤の再発と新生を区別して考える必要がある.症例 6 , 7 (Fig. 4, 5) は，動脈瘤が形成された場所はクリップの 近傍であり，最初の動脈瘤とは別に形成されたように思 われ判断に迷うところであるが，今回の検討ではクリッ プと同一部位に動脈瘤が形成されたものを「再発」，まっ たく別の場所に形成されたものを「新生」として検討し た。

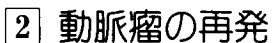

動脈瘤の再発に関する報告としては，1965 年に McKissock ${ }^{16)}$ が報告した, 中大脳動脈瘤クリッピング術 後 11 年目に再発した症例が最初であるとされている。そ の後多くの症例報告がなされているが(6) 10)14)201)，クリッ ピング術を行った全症例を長期間追跡調査した報告は少 ない，再発率に関し鮫島ら ${ }^{21)}$ は 2.1\% (3/141 例)，桜井 $ら^{20)}$ は $0.9 \%(4 / 473)$, Lin $~^{14)}$ は全手術症例の約 $1 \%$ と 報告している．今回の検討では，出血例のうち動脈瘤の 再発による再出血例は 1 例のみであり，再発率は $0.4 \%$ であった。 wrappingでは手術に用いた materialにより 予後は異なるが, 術後の再出血の報告は多い. Todd ら ${ }^{25)}$ は muslin gauze による wrapping 例において $18.3 \%$ $\left(11 / 60\right.$ 例) の再破裂を, Minakawa $ら^{18)}$ は術後平均 4 年 間で $26 \%$ (6/23 例) の再出血を報告している。これらと 比較してもクリッピング術後の再出血率は明らかに低
く，クリッピング術はきわめて信頼性が高いといえる。 次に再発の時期であるが，きわめて早く再発した症例 として，浅利ら ${ }^{1)}$ は術後 8 日目に動脈溜の再発が確認さ れ，急速に増大し 12 日目に破裂し死亡した症例を報告し ている。また前田ら ${ }^{15)}$ も術後 10 日目に再発を確認し，再 クリッピング術を行っている。しかしこれらはむしろ例 外的な症例であろう。一般に再発までに要する期間は， 数年〜数十年程度と報告されている( ${ }^{6)}{ }^{10) 20)}$. 逆に 24 年後 に residual neck から動脈瘤が形成された症例も報告さ れている ${ }^{14)}$ 。われわれの症例では，再発が確認されたの は術後 22 年目であった。

再発の原因に関して，鮫島ら ${ }^{21)}$ の検討では，1960 年代 には incomplete clipping の症例が多く，1970 年代には クリップの破損， slip out が比較的多く報告されている. しかし手術手技の向上，器具の改善に伴ってこれらの報 告は減少し，1980 年代には complete clipping にもかか わらず再発した症例の報告が散見されるようになった。 incomplete clipping と再発との関係はよく知られて いる. 1967 年の Drake ら ${ }^{3)}$ の報告では，70 例中 25 例 (35.7\%) に incomplete clipping を認め，そのうち 4 例 $(16 \%)$ が再出血している。しかし手術手技の向上により incomplete clipping の割合は急速に減少して, 1973 年の Drake らの報告 ${ }^{4)}$ では $13.1 \%$ (43/329 例) となっており， 1979 年には片倉ら ${ }^{12)}$ が $7.1 \%$ (41/578 例）と報告してい る. Lin ら ${ }^{14)}$ は residual neck と再発率との関係を検討 し，頸部を $1 \mathrm{~mm}$ 以上残した場合再発率が高く，ただち に再手術の必要はないが，十分な follow up が必要であ ると述べている。

complete clipping にもかかわらず, 再発した症例も知 られている. Sakaki ら ${ }^{22)}$ は, 後交通動脈瘤クリッピング 術後患者 931 例を $4 \sim 17$ 年間追跡調査し， 7 例に再発を 確認しているが，そのうち 5 例は術後血管撮影にて com. plete clipping と判断された症例であった。こうした症例 の説明として，(1) temporary clip による内膜の破損， (2) permanent clip 自体による動脈壁の変性・脆弱化, (3) microscopic な頸部の残存, (4) 動脈瘤の近傍または隣 接部に小膨褔や血管壁の薄い部分が存在していた，など が想定されている5) 10)24)．今回の症例では術後の血管撮 影は行われておらず，再発の原因に関しては明らかにで きなかった。

\section{3 動脈瘤の新生}

1964 年. Graf $ら^{8)}$ の報告が，動脈瘤新生に関する最初 の報告である。彼らは右中大脳動脈瘤術後 3 年目に左中 大脳動脈瘤破裂により死亡した症例を報告し， de novo 
aneurysm の名称を与えている，その後多くの症例が報 告されているが11)17)19)，多くは内頸あるいは総頸動脈結 禁術後に対側に動脈瘤が形成された症例であり919), hemodynamic stress が原因と考えられている. Miller $ら^{17)}$ は 620 例を $3 〜 20$ 年間追跡調査した結果, 7 例 （1.1\%）の動脈瘤の新生を報告している。今回のわれわ れの検討では，2 22 年間の追跡調査で 257 例中 4 例 （1.6\%）が，新生動脈瘤によるくも膜下出血をきたして いた.

新生動脈瘤の形成部位として, mirror image の場所に 形状されることが多いとされている. Crompton ${ }^{21}$ はそ の原因として, 動脈瘤の mirror site は他の部位に比べ, 中膜の欠損が大きいことを指摘している。われわれの症 例でも，4 例中 2 例が mirror image の場所に動脈瘤が 形成されていた。

\section{4 術後の follow up}

破裂脳動脈瘤によるくも膜下出血の割合は，11〜16 人/人口 10 万/年と報告されている.今回の結果から同様 の計算を試みると, 平均 8.8 年の追跡期間中に 257 例中 5 例が動脈瘤の再発または新生によるくも膜下出血をき たしており，これは 221 人/10万(clipping 術後患者)/年 となる。近年 MRAを用いた末破裂脸動脈瘤のスクリー ニングが普及し，〈も膜下出血の予防に成果を上げてい るが, 動脈溜の術後患者は最も high risk group に属す ると考えられる。

前述のように, 動脈瘤は術後再発までに平均 10 年, 時. には20年以上かかることを考慮すると10)14)21)，かなり 長期の follow up が必要である。当院では，未破裂脳動 脈瘤のスクリーニングに MRA, IV-DSA, 3D-CT angiography を使用しているが，MRA および CTは，最も 必要すると動脈瘤付近の情報がクリップによるアーチ ファクトにより消されてしまうため, 残念ながら動脈瘤 の術後 follow up には利用することができない. また， IV-DSA は空間分解能に限界があり，三次元的な観察が できないため7)，偽陽性・偽陰性率が高いことが指摘され ている、深谷らうは当院におけるIV-DSAによる未破裂 脳動脈瘤スクリーニングの結果を報告しているが，偽陽 性，偽陰性はそれぞれ 36\%，21\%であった。DSA では 4 $\mathrm{mm}$ 以下の動脈瘤は発見しにくいと言われており, DSA による follow up の限界といえるが，4 mm 以下の動脈 瘤は破裂しにくいことも知られており，致命的な欠点と はいえない，偽陽性の原因の多くは，血管の重なりや屈 曲によるものであった. 術後 follow up に用いる場合に は，術前の血管撮影と比較することにより再発と区別す
ることができるため，スクリーニングに用いる場合に比 し偽陽性は少ないと考えられる。放射線や造影剤の使用, 空間分解能の限界などを考えると, IV-DSA は理想的な 検査ではないかもしれないが，クリッピング術後の follow up には現段階では最も有用である。

\section{文 献}

1）浅利正二, 国塩勝三, 角南典生, 山本祐司, 桜井 勝, 鈴木健二：クリッピング後その近傍に発生し極めて短期 間に破裂に至った脳動脈瘤。脳外 14：587-591，1986.

2) Crompton MR: The pathogenesis of cerebral aneurysms. Brain 89:797-814, 1966.

3) Drake $C G$, Vanderlinden $R G$ : The late consequences of incomplete surgical treatment of cerebral aneurysms. J Neurosurg $27: 226-238,1967$.

4) Drake CG, Allcock JM : Postoperative angiography and the slipped clip. J Neurosurg $39: 683-689,1973$.

5) Dujovny M, Osgoog CO, Barrionuevo PJ, Perlin A, Kossovsky N : SEM evaluation of endothelial damage of following temporary middle cerebral artery occlusion in dogs. J Neurosurg 48:42-48, 1979.

6）海老名国彦, 岩淵 隆, 鈴木重治, 鈴木幹男: 脳動脈瘤 クリップ後の再発.脳外 $10 ： 1195-1201 ， 1982$.

7）深谷展行，佐伯直勝，角南兼朗，星誠一郎，小宮博一： 経静脈的 DSA一脳動脈瘤のスクリーニング法としての 有用性. 臨放 35：1005-1010，1990.

8) Graf CJ, Hamby WB : Report of a case of cerebral aneurysm in an adult developing apparently de novo. J Neurol Neurosurg Psychiatry 27 : 153-156, 1964.

9) Gurdjian ES, Linder DW, Thomas LM : Experience with ligation of the common carotid artery for treatment of aneurysms of the internal carotid artery. $J$ Neurosurg 23:311-318, 1965.

10）原岡 襄, 三輪哲郎, 東 幸郎, 伊藤良則, 古場群巳 : 脳動脈溜クリッピング後の再発例の検討. 脳卒中の外科 $15: 245-255,1987$.

11）池田清延, 早瀬秀男, 林実, 山本信二郎：前動脈瘤 病変と動脈瘤の新生. 脳外 $12: 1151-1158,1984$.

12）片倉隆一, 畑中光昭, 鈴木二郎：脳動脈溜直接手術後陰 影残存例の検討. 脳外 $7: 139-148,1979$.

13) Klemme WM : Hemorrhage from a previously undemonstrated intracranial aneurysm as a late complication of carotid artery ligation. Case report. J Neurosurg 46:654-658, 1977.

14) Lin T, Fox AJ, Drake CG: Regrowth of aneurysm sacs from residual neck following aneurysm clipping. $J$ Neurosurg 70:556-560, 1989.

15）前田泰孝, 藤田敏晃, 山本 聡, 狩野光将：Miss clip を 思わせた脳動脈瘤再発例. Neurol Med Chir (Tokyo) $29:$ 319-323, 1989.

16) McKissock $W:$ Recurrence of an intracranial aneurysm after excision. I Neurosurg 23:547-548, 1965.

17) Miller CA, Hill SA, Hunt WE: De novo aneurysms. A clinical review. Surg Neurol 24:173-180, 1985.

18) Minakawa T, Koike T, Fujii $Y$, Ishii R, Tanaka R, Arai $\mathrm{H}$ : Long term results of ruptured aneurysms treated by coating. Neurosurgery 21:660-663, 1987.

19）貫井英明，長屋孝雄，宮城 修，玉田潤平，金子的実， 佐々木秀夫, 三塚 繁, 川淵純一, 河野徳雄, 狩野忠雄： 
脳動脈瘤の成因および増大，破裂に関する臨床的検討。 Neurol Med Chir (Tokyo) 22:437-445, 1982.

20）桜井芳明, 小川 彰, 嘉山孝正: 脳動脈瘤術後の再破裂 症例の検討一長期予後調査の結果から. 脳卒中の外科 15：243-248, 1987.

21）鮫島寛次, 溝上 徹, 牛久保行男, 佐藤隆雄, 古井信夫, 野中博子：脳動脈瘤術後長期再発例の検討。脳外 12 ： 873-881, 1984.

22) Sakaki T, Takeshima T, Tominaga M, Hashimoto $H$, Kawaguchi S: Recurrence of ICA-PCoA aneurysms after neck clipping. J Neurosurg 80:58-63, 1994.

23) Sato K, Fujiwara S, Kameyama M, Ogawa A, Yoshimoto T, Suzuki J : Follow-up study on ruptured aneurysms treated by wrapping. Neurol Med Chir (Tokyo) $30: 734-737,1990$.

24）関貫聖二, 岡島和弘, 佐藤浩一, 日下一昌：脳動脈瘤ク リッピング術後の再発. 脳外 $13: 1357-1362,1985$.

25) Todd NV, Tocher JL, Jones PA, Miller JD : Outcome following aneurysm wrapping: A 10-year follow-up review of clipped and wrapped aneurysms. I Neurosurg 70:841-846, 1989.

26) Winn HR, Richardson AE, Jane JA : Late morbidity and mortality of common carotid ligation for posterior communicating aneurysms. A comparison to conservative treatment. J Neurosurg 47:727-736, 1977.

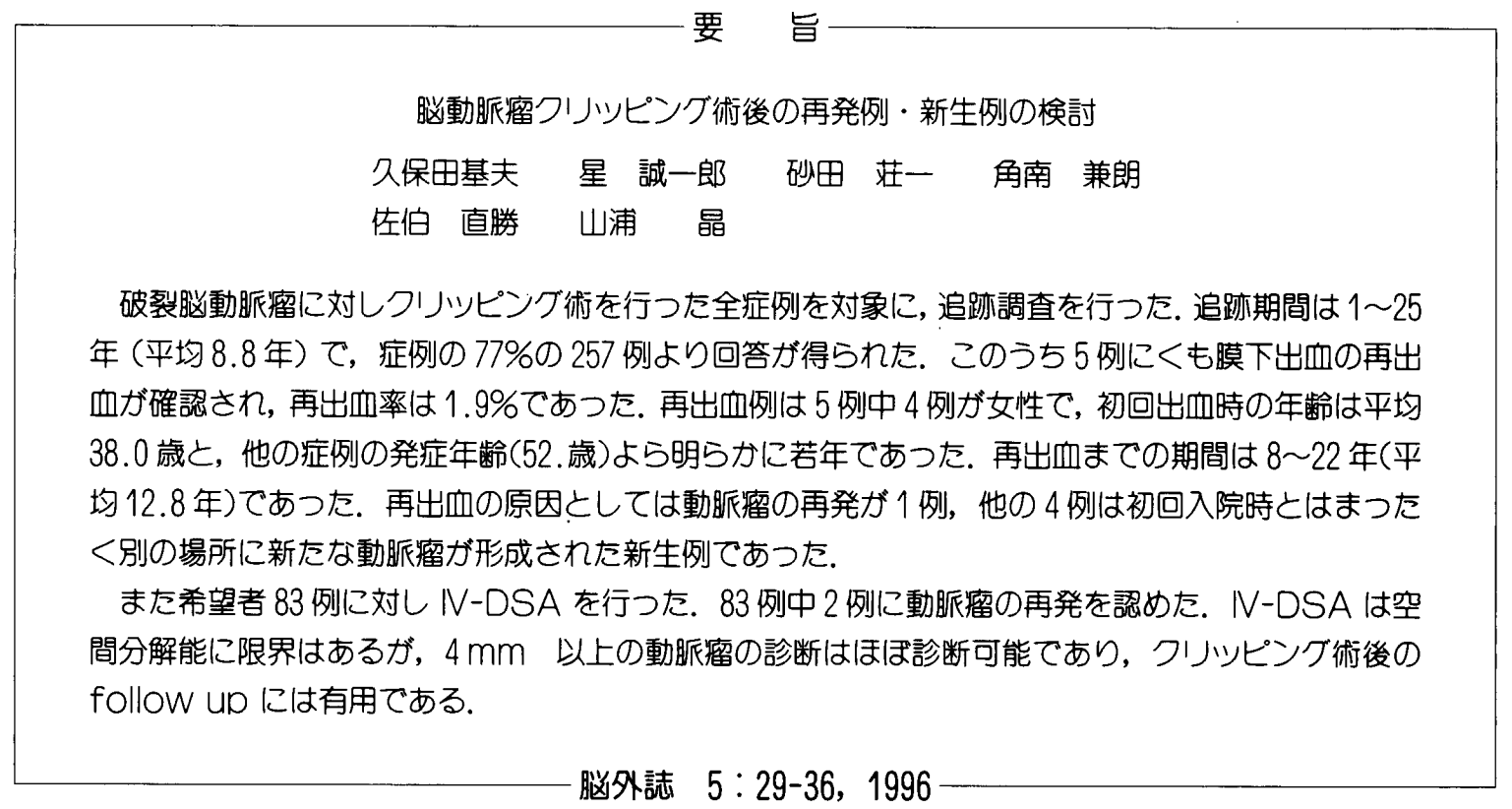

